\title{
Uptake and effect of radioiodine exposure on SKBR-3 cell lines
}

\author{
Miftah Irramah ${ }^{1}$, Yulia Kurniawati ${ }^{2,3}$, VY. Susilo ${ }^{4}$, S. Setiyowati ${ }^{4}$, Aisyah Elliyanti ${ }^{1,3}$ \\ 1. Department of Medical Physics, Faculty of Medicine, Universitas Andalas; 2. Department of \\ Radiology, Faculty of Medicine, Universitas Andalas; 3. Department of Radiology, Division of Nuclear \\ Medicine, dr. M. Djamil Central Public Hospital, Padang; 4. Center of Radioisotopes and Radio \\ pharmaceuticals Technology, National Nuclear Energy Agency, Kawasan Puspiptek Serpong, \\ Indonesia
}

Correspondence: Aisyah Elliyanti; email: aelliyanti@med.unand.ac.id

\begin{abstract}
Radioiodine has been known as an adjuvant therapy for thyroid cancer. Beside for thyroid cell, radioiodine is reported to be taken up by breast cell. It may be proposed as an alternative for breast cancer therapy. Objective: The study aim was to analyze an uptake of radioiodine and cell proliferation rate of breast cancer cell after the exposure of radioiodine. Methods: This study used SKBR-3 cell line as representative of Human Epidermal Growth Factor Receptor (HER2+) subtype. The cells were planted in DMEM medium added $10 \%$ fetal bovine serum (FBS), panstrep $1 \%$ and amphotericin $\mathrm{B}$. The cells were grown until $80 \%$ confluent and then stripped. Subsequently the cells were sub-cultured on plates 12 and 6 wells respectively for measured uptake of radioiodine and cell proliferation rate after the exposure. Radioiodine uptake was calculated by sum efflux of 125 lodine $\left({ }^{125} \mathrm{I}\right)$ and the amount of uptake after the addition of $95 \%$ ethanol. Cell proliferation rate was measured by calculated by using clonogenic assay after iodine-131 $\left({ }^{131} \mathrm{I}\right)$ exposure. Results: The average of iodine uptake was $194 \pm 50$ $\mathrm{cpm} / 106$ cell. The average cell proliferation after radioiodine exposure was $54 \% \pm 5 \%$; Conclusions: Radioiodine is taken by SKBR-3 cells and it reduced cell proliferation rate. This finding shows an opportunity for radioiodine as an alternative therapy for breast cancer. Another studies are needed to understand of cell death the mechanism.
\end{abstract}

Keywords: radioiodine; proliferation; uptake

\section{INTRODUCTION}

Treatment of breast cancer consists of surgery followed by adjuvant therapy such as hormone therapy, radiation, chemotherapy and immunotherapy. The cost of adjuvant therapy, especially chemotherapy and immunotherapy can reach hundreds of millions. ${ }^{1}$ The financing of the treatment of breast cancer that continues to increase creates significant financial problems for patients and their families.
The type of adjuvant therapy is determined by the molecular types of breast cancer. Each molecular type of breast cancer has a different prognosis and response to chemotherapy. The HER2+ subtype is a group which is sensitive to chemotherapy but has limited response to the therapy. It has a worse prognosis than the luminal group. $^{2,3}$ Other adjuvant therapies are needed to increase the disease-free period and life expectancy for breast cancer patients, especially in the HER2+ subtype. 
The ideal cancer adjuvant therapy, which is selective in target cells with minimal side effects and low prices, will make a very significant contribution to the management of breast cancer.

Radioiodine $\left({ }^{131} \mid\right)$ has been used for more than 60 years as adjuvant therapy for thyroid cancer and has become an integrated part of its management. ${ }^{4}$ The therapy has increased the disease-free period and life expectancy in thyroid cancer patients with recurrent or metastatic cases. The ability of the thyroid gland to capture and maintain iodide in cells is the basis for the use of ${ }^{131}$ I for the diagnosis and treatment of thyroid cancer. ${ }^{5}$ SKBR-3 cell line is a breast cancer HER2+ subtype. A study reported that, SKBR-3 cell expresses Natrium lodide Symporter (NIS) which has important role for iodine transport cross the membrane. ${ }^{6,7}$ The purpose of this study is to analyzed an uptake of ${ }^{131}$ I and cell proliferation rate of SKBR-3cell after the exposure of ${ }^{131}$ I.

\section{METHODS}

SKBR-3 cell line was used in this study. The study was conducted at the cell culture Laboratory of Radioisotope and Radiopharmaceutical Technology (PTRR) of National Nuclear Body of Indonesia. SKBR3 cell line from ATCC (American Type Culture Collection). Radioiodine $125 \mathrm{I}$ was used measure the uptake and 131 l was used to measure the toxicity.

\section{Cell Culture}

Cells were planted on $25 \mathrm{~cm}^{3}$ flask in DMEM medium, added $10 \%$ fetal bovine serum (FBS), panstrep $1 \%$ and amphotericin B. Cells were grown until $80 \%$ confluent and then stripped. Subsequently the cells were sub-cultured on plates 12 and 6 well for measured uptake and toxicity of radioiodine.

\section{Measurement of Radioactive lodine Uptake}

Measurements of radioiodine uptake were carried out by modification of methods by Knostnam. ${ }^{8}$ Cells were planted on 12 culture plates, 200,000 cell/well for 24 hours. Each well added $2 \mu \mathrm{C}{ }^{125} \mathrm{I}$ in (Hanks' balance salt solution) HBSS $+10 \mathrm{mM}$ HEPES $(\mathrm{PH} 7.3)$ and incubated at $37^{\circ} \mathrm{C}, \mathrm{CO}_{2}$ level $5 \%$ for one hour. Then, the cells were trypsinazed and distributed in $1 \mathrm{~mL}$ (106 cell)/tube. Efflux was counted every 15 minutes until 1 hour and followed by incubation in $1 \mathrm{~mL}$ of $95 \%$ ethanol at room temperature for 20 minutes to release intracellular ${ }^{125}$. The uptake was calculated by sum of efflux calculations and the amount of uptake after the addition of $95 \%$ ethanol. The studies were carried out three times repeated in two separate experiments.

\section{Cell Proliferation Rate}

The toxic effect was assessed by clonogenic assay. It refers to the procedure performed by Kogai et al. ${ }^{9}$ Cells were planted on culture plates with 12 wells and wait until $80 \%$ confluent. Each well added $1 \mu \mathrm{C} \mathrm{ml}$ of ${ }^{131} \mathrm{I}$ in HBSS $+10 \mu \mathrm{M} \mathrm{Nal}+10 \mathrm{mM}$ 
HEPES (PH 7.3). In the control group only HEPES + 10MM was given (PH 7.3), then the cells were incubated at $37^{\circ} \mathrm{C}$, with $\mathrm{CO}_{2}$ levels of $5 \%$ for 7 hours. After the incubation period was complete, the cells were quickly washed with cold HBSS and were thinned with $0.05 \%$ trypsin EDTA. The cells were replanted on a well 6 culture plate with a number of 1000 cells/well. After ten days, the cells were washed with PBS, fixed and stained with a mixture of $0.5 \%$ crystal violet in $50 / 50$ methanol/water for 30 minutes. Then the cell is washed with water and dry in room temperature. The next day a number of colonies were counted which were visible to the well treated and the results were compared to the colonies formed in well controls that were not given radioactive iodine.

\section{Statistical Analysis}

Data analyzed by statistic with t-test difference two group and using ANOVA for more than two group with significance level $p<0.05$.

\section{RESULTS AND DISCUSSIONS}

The confluent cells were incubated with radioiodine for an uptake and a cell proliferation rate analysis as shown in Figure 1 . The mean of radioiodine uptake was $194 \pm 50 \mathrm{cpm} / 106$ cells. The average cell proliferation after ${ }^{131}$ I exposure was $54 \% \pm 5 \%$ and control $99 \% \pm 2 \%$, with $\mathrm{p}=0.005$ (Figure 2).

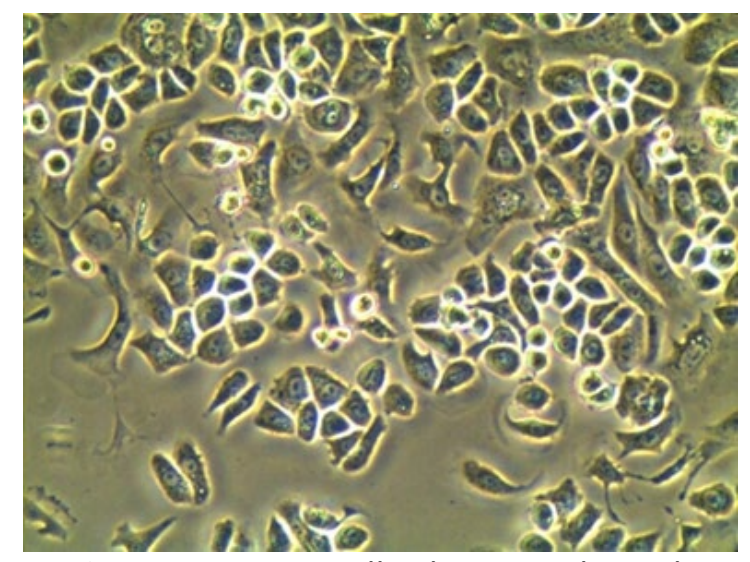

Figure 1. SKBR-3 cell culture results with confluent $80 \%$.

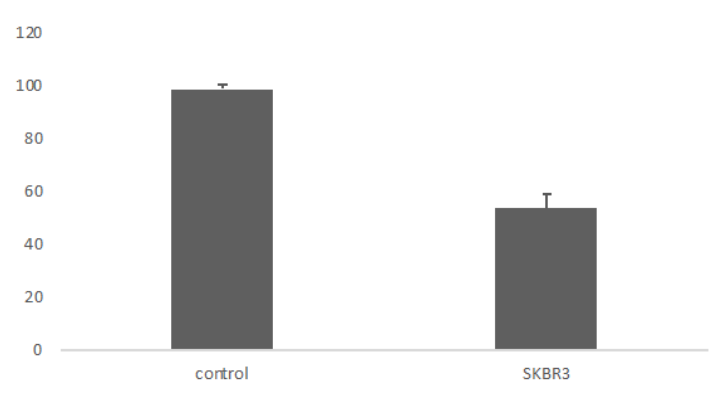

Figure 2. Cell proliferation of SKBR3 cell after radioiodine was $54 \% \pm 5 \%$ and control $99 \% \pm 2 \%$, with $\mathrm{p}=0.005$

$\mathrm{I}-131$ is widely used for diagnosis and treatment of benign thyroid diseases. ${ }^{10}$ Rates of thyroid cancer in women with a history of breast cancer are higher than expected. Similarly, rates of breast cancer in those with a history of thyroid cancer are increased. Explanations for these associations include detection bias, shared hormonal risk factors, treatment effect, and genetic susceptibility. ${ }^{11}$ Thyroid and breast cancer are two of the malignant diseases with highest incidence in females. Based on clinical experience, breast and thyroid cancer often occur synchronously. Therefore, thyroid and breast cancer might share some common etiological factors. ${ }^{12}$ 
I-131 is an effective and low-risk therapy modality in well-differentiated thyroid cancer patients post near-total thyroidectomy. Extra thyroidal tumors such as breast cancer are known to be able to uptake ${ }^{131}$ I. ${ }^{13}$ HER2+ is one of the most studied tumor-associated antigens for cancer immunotherapy. It is overexpressed in various human cancers, such as breast. ${ }^{14}$ Up to $70-90 \%$ breast cancer cell expressed NIS included HER2+ subtype. ${ }^{6,15-17}$ NIS is a co-transporter of iodine to crossed cell membrane. In this study, SKBR-3 cell which represent HER2+ subtypes taken up of radioiodine. The exposure of radioiodine reduced cell proliferation significantly when is compared to the control cell $(p=0.005)$. This finding is in line with previous study. ${ }^{18}$ I-131 is caused DNA damage and inducing secondary immuno-reactivity. The effects of ${ }^{131}$ I on malignant cells appears to be depended on absorbed dose. ${ }^{131} \mathrm{I}$-mediated cellular damage, and some studies observed a necrotic cellular death following high-dose ${ }^{131}$ | treatment. ${ }^{19}$ The exact mechanisms of cellular death of SKBR3 cell have not yet been fully elucidated. Further studies are needed to uncover this issue.

\section{CONCLUSSIONS}

Radioiodine was taken by SKBR3 cells. Its exposure, reducing of cellular proliferation rate significantly. It may open an opportunity for ${ }^{131}$ I as an alternative therapy for breast cancer. However, cell death mechanism that activated after ${ }^{131}$ I exposure should be explored further in order to fully delineate the cell response.

\section{FUNDING}

This research was funded by Faculty of Medicine, Universitas Andalas thru PNBP Project 2017 Number 85/SPK/PNP/FKUNAND-2017.

\section{ACKNOWLEDGEMENT}

Riska Helfina for technical assistance.

\section{REFERENCES}

1. American Cancer Society. The Costs of Cancer. [Internet]. 2017. Available in: [Link].

2. Aysola K, Desai A, Welch C, Xu J, Qin Y, Reddy V, et al. Triple Negative Breast Cancer - An Overview. Hereditary Genet. 2013; 2013(Suppl 2):001. doi: 10.4172/2161-1041.S2-001. [PMC free article].

3. O'Brien KM, Cole SR, Tse CK, Perou CM, Carey LA, Foulkes WD, et al. Intrinsic breast tumor subtypes, race, and long-term survival in the Carolina Breast Cancer Study. Clin Cancer Res. 2010; 16(24):6100-10. doi: 10.1158/1078-0432.CCR-10-1533. [PubMed] [PMC free article].

4. Reddy S, Charles M, Kumar M, Reddy B, Anjaneyulu C, Raju G, et al. Differentiated Thyroid CancerTreatment: State of the Art. Int J Mol Sci. 2017; 18(6):E1292. doi: 10.3390/ijms18061292. [PubMed] [PMC free article]. 
5. Micali S, Bulotta S, Puppin C, Territo A, Navarra M, Bianchi G, et al. Sodium iodide symporter (NIS) in extrathyroidal malignancies: focus on breast and urological cancer. BMC Cancer. 2014; 14:303. doi: 10.1186/1471-2407-14-303. [PubMed] [PMC free article].

6. Hingorani M, Spitzweg C, Vassaux G, Newbold K, Melcher A, Pandha H, et al. The biology of the sodium iodide symporter and its potential for targeted gene delivery. Curr Cancer Drug Targets. 2010; 10(2):242-67. doi: 10.2174/156800910791054194. [PubMed] [PMC free article].

7. Elliyanti A, Putra AE, Sribudiani Y, Noormartany N, Masjhur JS, Achmad TH, et al. Epidermal Growth Factor and Adenosine Triphosphate Induce Natrium lodide Symporter Expression in Breast Cancer Cell Lines. Open Access Maced J Med Sci. 2019; 7(13):2088-2092. doi: 10.3889/oamjms.2019.620. [PubMed] [PMC free article].

8. Knostman KA, Cho JY, Ryu KY, Lin X, McCubrey JA, Hla T, et al. Signaling through $3^{\prime}, 5^{\prime}$-cyclic adenosine monophosphate and phosphoinositide- 3 kinase induces sodium/iodide symporter expression in breast cancer. J Clin Endocrinol Metab. 2004; 89(10):5196-203. doi: 10.1210/jc.2004-0907. [PubMed].

9. Kogai T, Taki K, Brent G. Enhancement of sodium/iodide symporter expression in thyroid and breast cancer. Endocr Relat Cancer. 2006; 13(3):797-826. doi: 10.1677/erc.1.01143. [PubMed].

10. Hieu TT, Russell AW, Cuneo R, Clark J, Kron T, Hall P, et al. Cancer risk after medical exposure to radioactive iodine in benign thyroid diseases: a meta-analysis. Endocr Relat Cancer. 2012; 19(5):645-55. doi: 10.1530/ERC-12-0176. [PubMed].

11. Nielsen SM, White MG, Hong S, Aschebrook-Kilfoy B, Kaplan EL, Angelos P, et al. The BreastThyroid Cancer Link: A Systematic Review and Meta-analysis. Cancer Epidemiol Biomarkers Prev. 2016; 25(2):231-8. doi: 10.1158/1055-9965. [PubMed] [PMC free article].

12. Dong L, Lu J, Zhao B, Wang W, Zhao Y. Review of the possible association between thyroid and breast carcinoma. World J Surg Oncol. 2018; 16(1):130. doi: 10.1186/s12957-018-1436-0. [PubMed] [PMC free article].

13. Elliyanti A, Susilo VY, Setiyowati S, Ramli M, Masjhur J, Achmad T. Uptake and Cytotoxicity Characterization of Radioiodine in MCF-7 and SKBR3 Breast Cancer Cell Lines. Atom Indonesia. 2016; 42(3):145-9. doi: 10.17146/aij.2016.586.

14. Okarvi SM, AlJammaz I. Development of the Tumor-Specific Antigen-Derived Synthetic Peptides as Potential Candidates for Targeting Breast and Other Possible Human Carcinomas. Molecules. 2019; 24(17):E3142. doi: 10.3390/molecules24173142. [PubMed] [PMC free article].

15. Beyer S, Jimenez RE, Shapiro CL, Cho J, Jhiang SM. Do cell surface trafficking impairments account for variable cell surface sodium iodide symporter levels in breast cancer?. Breast Cancer Res Treat. 2009; 115(1):205-12. doi: 10.1007/s10549-008-0059-5. [PubMed] [PMC free article].

16. Wapnir IL, van de Rijn M, Nowels K, Amenta PS, Walton K, Montgomery K, et al. Immunohistochemical profile of the sodium/iodide symporter in thyroid, breast, and other carcinomas using high density tissue microarrays and conventional sections. J Clin Endocrinol Metab. 2003; 88(4):1880-8. doi: 10.1210/jc.2002-021544. [PubMed].

17. Knostman KA, McCubrey JA, Morrison CD, Zhang Z, Capen CC, Jhiang SM. PI3K activation is associated with intracellular sodium/iodide symporter protein expression in breast cancer. BMC Cancer. 2007; 7:137. doi: 10.1186/1471-2407-7-137. [PubMed] [PMC free article]. 
18. Metso S, Auvinen A, Huhtala H, Salmi J, Oksala H, Jaatinen P. Increased cancer incidence after radioiodine treatment for hyperthyroidism. Cancer. 2007; 109(10):1972-9. doi: 10.1002/cncr.22635. [PubMed].

19. Riley AS, McKenzie GAG, Green V, Schettino G, England RJA, Greenman J. The effect of radioiodine treatment on the diseased thyroid gland. Int J Radiat Biol. 2019; 95(12):1718-1727. doi: 10.1080/09553002.2019.1665206. [PubMed]. 